\title{
Analyzing the contribution of crop diversification in improving household food security among wheat dominated rural households in Sinana District, Bale Zone, Ethiopia
}

\author{
Dereje Derso Mengistu* ${ }^{*}$, Degefa Tolossa Degaga and Abraham Seyoum Tsehay
}

\begin{abstract}
Background: Agriculture is considered an important strategy for overcoming many of the emergencies faced by rural households in developing countries. In rural Ethiopia household access to food largely depends on what the household grows, either because they consume what they grow, or they purchase food with the income earned from what they grow. This study examines effect of crop diversification on food security and determinants of household food security among rural farm households of Sinana District, Oromia Regional state. The study uses a multi stage sampling procedure to select 384 sample households. Data were collected using a household survey, a focus group discussant (FGD), and key informant interviews. Ordinary least squares regression (OLS) and multinomial logistic regression model were used to analyze the data collected.

Results: We found that crop diversification had a positive and significant effect on household food security. Although crop diversification was positively associated with household food security, several other factors were found to be as or more important in increasing household food security. The education of the household head, access to irrigation system, livestock owned, total income, and remittance positively affected household food security. In contrast, age of household head and distance to nearest market were negatively associated with food security.

Conclusions: The study conclude that any effort to increase household food security should consider empowerment of farmers through adequate training and informal education, enhancing crop diversification, strengthening the rural infrastructural development (roads, market centers, and cooperatives).
\end{abstract}

Keywords: Food security, Multinomial logistic model, Rural households, Bale zone

\section{Background}

In developing countries, agriculture contributes to the entire economy and a source of food. It directly contributes to food security by making more food available or by enabling farm households to access using their farm

*Correspondence: derejso@gmail.com

Center for Rural Development, College of Development Studies, Addis

Ababa University, Addis Ababa, Ethiopia income. Agriculture is also an important strategy to overcome many of the emergencies faced by rural in developing countries $[1,2]$. In rural Ethiopia households' access to food largely depends on what the household grows, either because they consume what they grow, or they purchase food with the income earned from what they grow.

Food insecurity and undernutrition have been the major development challenges of developing countries 
$[3,4]$. Food security is achieved when all people, at all times, have physical, social, and economic access to sufficient, safe, and nutritious food that meets their dietary needs and food preferences for an active and healthy life [5]. Despite growing national and global commitment towards the food and nutrition problem, a significant proportion of the population is food insecure and suffers from micronutrient deficiencies [6].

A latest report by Food and Agriculture Organization (FAO) shows that $10.9 \%$ of the world, $20.4 \%$ of Africa and $31.4 \%$ of Eastern Africa people were undernourished in 2017 [7]. Likewise, study [8] shows that in many developing countries, the condition of household food security depends mainly on physical and economic means (accessibility). It stated that economic, social, and environmental sustainability are essential for the accessibility to food for all people. Hence, without integrating sustainability to food security, it is impossible for policymakers to mitigate food insecurity. In Ethiopia, about $80 \%$ of the society lives in rural areas under insufficient infrastructural facilities. The majority of the households are smallholders [9]. They often face recurrent drought, weather variability, and food insecurity. Endalew et al. [10], for instance, came across that about $10 \%$ of Ethiopians were chronically food insecure throughout the normal year and this figure increased to $15 \%$ during frequent drought periods. In connection with the situation of food insecurity, in 2018, the Global Food Security Index (GFSI) of the Economist Intelligence Unit (EIU) ranked Ethiopia as 100th among 113 countries based on food affordability, availability, quality, and safety. According to the EIU Index [11], Ethiopia is a state with $28.8 \%$ prevalence of undernourishment, and very low in diet diversification, sufficiency of food supply, micronutrient availability, and food consumption as a share of household expenditure.

Albeit, household food insecurity, hunger and undernutrition have major implications for smallholder farmers in Ethiopia. Undernutrition is an underlying cause of $53 \%$ of infant and child deaths. Over the past decade, rates of stunting and underweight have decreased gradually but it remains high with $44 \%$ of children under-five stunted and $29 \%$ underweight $[9,12]$.

Food insecurity in Ethiopia is derived primarily from dependence on undiversified livelihoods based on low output rain-fed agriculture [13]. The challenges are traced back to poor infrastructure, declining soil fertility and climate change, among others. Like most part of Ethiopia, Sinana District, the focus of this study, has been stricken by poverty and experiencing household food insecurity [14]. Consequently, smallholder farmers in the areas are forced or encouraged to diversify crop production in order to overcome twine-objective of stabilize their food stocks and incomes. Crop diversification, characterized by, cultivating more than one variety of crops belonging to the same or different species in a given area, is the mechanism to overcome household food insecurity problems [15]. It is a method of developing a resilient agricultural system, especially where communities depend largely on agricultural products (food and fodder) for his or her livelihoods $[15,16]$. Pellegrini and Tasciotti [17] illustrated that the number of crops produced highly contributes to household food security and dietary diversity. They also argued that crop diversification has a double role: it has high impact on households' diets and, other things being equal, it increases agricultural revenues. A study by [18] also suggested that families who grow a diverse set of crops are less likely to be poor as compared with households specializing in their crop production. According to [19], cultivating several crop species can also help smallholder farmers to manage price and production risks. Ultimately, crop diversification contributes to improved yield for the smallholder farmer, which in turn translated into more and a variety of food for consumption and marketable surpluses from production. Therefore, this study aimed at examining the effect of crop diversification on food security (access and utilization) and identifying determinants of household food security among rural households of the Sinana District, Ethiopia.

\section{Materials and methods}

\section{Sinana Woreda setting}

The study was conducted in Sinana District which is located in Bale zone (Fig. 1). It is bounded with Goro and Ginir in East, Dinsho in West, Agarfa and Gasera in North and Goba and Barbare Oreda in the south. The district lies between $6^{\circ} 55^{\prime} 00^{\prime \prime}$ to $7^{\circ} 18^{\prime} 00$ North and $39^{\circ}$ $53^{\prime} 00^{\prime \prime}$ to $40^{\circ} 26^{\prime} 00^{\prime \prime}$ East. The altitude of the district ranges from 1650 to $2950 \mathrm{~m}$ a.s.l.

The district has 20 rural kebeles. The total area of the district is about $1168 \mathrm{~km}^{2}$. About $73.54 \%$ is plain land, $3.7 \%$ is hills, $9.6 \%$ is mountains, $12.3 \%$ is rugged and $0.86 \%$ is gorge. The annual average temperature is $16.5^{\circ} \mathrm{C}$, whereas the minimum and maximum temperature is $9{ }^{\circ} \mathrm{C}$ and $23^{\circ} \mathrm{C}$, respectively. Rainfall pattern of the District is characterized by bi-modal rain fall distribution. The annual average rainfall is $1105 \mathrm{~mm}$, whereas the minimum and maximum rainfall is 1060 and $1150 \mathrm{~mm}$, respectively [20].

With $99 \%$ of the population engaged in farming, agriculture is one of the economic activities of the district. Farmers in the district practice mixed farming that incorporates both crop and livestock. The major crops produced in the district are cereals, pulses and oil crops [14]. 


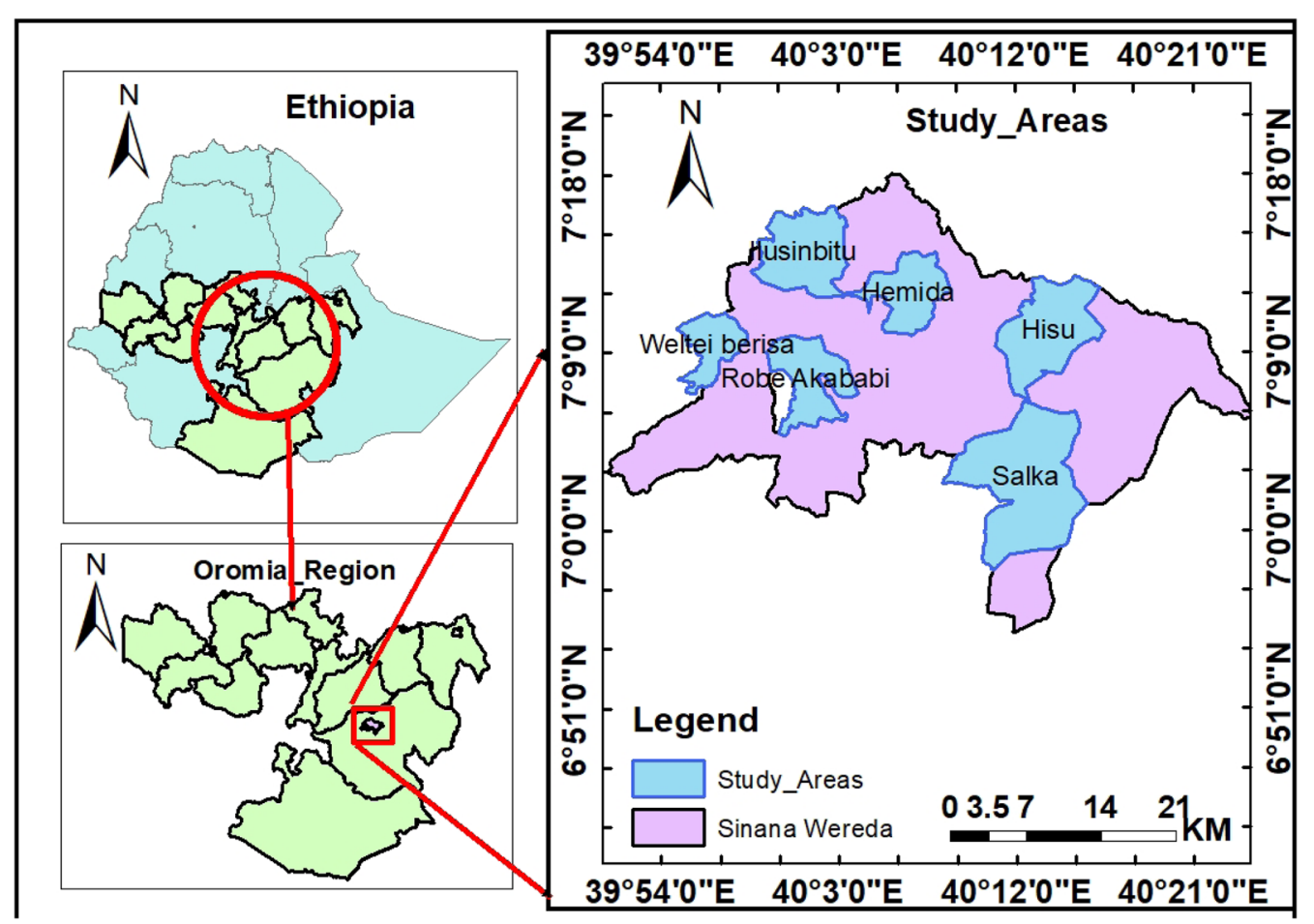

Fig. 1 Map of study area

\section{Study design}

The study employed a cross-sectional survey using a mixed methods research approach. The choice of mixed methods was dictated by the research problem under $[21,22]$. It involves a multi stage sampling technique to select sample kebeles and households surveyed. First, the district was selected purposively due to dominance and potential in wheat production. Second, representative Kebeles were selected using simple random sampling method. Third, respondent households were randomly selected from lists of names of household head in the Kebeles using computer-generated random number table.

The primary data were collected from the households, key informants such as, community elders, Development Agents (DAs), and Health Extensions and Researchers and different development experts in the district. Before starting the actual data collection, the questionnaire was pre-tested. Based on the pretest results, the necessary modifications were made to the questionnaire. Focus group discussions (FGDs) were also conducted with group of male and female on the issues related to economic activities, food security and home consumption behavior among rural households. Twelve FGDs, two in each selected kebeles were made to obtain important qualitative data.
In order to obtain a representative sample size, the study employed the sample size determination formula given by [23]

$$
n=\frac{N}{1+N\left(e^{2}\right)}=\frac{9768}{1+9768\left(0.05^{2}\right)}=\frac{9768}{1+24.42}=384
$$

where $n$ is the sample size, $N$ is the population size (total households in the six kebeles, which is 9768) and $e$ is the level of precision.

\section{Methods of data analysis}

The survey data were coded, organized, summarized and analyzed using descriptive, and econometric model analysis. STATA version 14.2 was used to aid data analysis. While the qualitative data were analyzed using narration and conceptual explanation, quantitative data were analyzed using Ordinary least square (OLS) method and a multinomial logit model.

\section{Crop diversification analysis}

The study adopted one of the widely used in crop diversification analysis called Herfindahl-Hirschman Index (HHI) to measure crop diversification to represent relative land sizes of farming activities undertaken by a given farm [24]. The crop diversification index (CDI) is an 
index of concentration. It has a direct relationship with diversification such that a zero value indicates specialization and a value greater than zero signifies crop diversification. The CDI is obtained by subtracting the Herfindahl index (HI) from one (1-HI). Precisely, the CDI is calculated as follows:

$$
p_{i}=\frac{A_{i}}{\sum_{i=1}^{n} A_{i}}
$$

where $P_{i}=$ proportion of $i$ th crop, $A_{i}=$ area under $i$ th crop (ha), $\sum_{i=1}^{n} A_{i}$ totalcropland(ha)andi $=1,2,3 \ldots, \mathrm{n}$ (numberofcrop)

$$
\begin{aligned}
& \text { HerfindahlIndex }=\mathrm{HI}=\sum_{\mathrm{i}=1}^{\mathrm{n}} \mathrm{p}_{\mathrm{i}}{ }^{2} \\
& \text { Crop diversification index }=\mathrm{CDI}=1-\mathrm{HI}
\end{aligned}
$$

\section{Food security analysis}

In this paper, we adopt Household Food Insecurity Access Score (HFIAS) and Dietary Diversity as a measure of household food security in the study sites.

\section{Household Food Insecurity Access Score (HFIAS)}

The HFIAS is a continuous measure of the degree of food insecurity (access) in the household in the past 30 days. Despite the limitations of all measures, the HFIAS has been found to be understandable and applicable across varying contexts [25]. Additionally, it has been identified as it uniquely able to detect aspects of food insecurity involving decreased access to a sufficient quantity or quality of food [26].

According to [27], the HFIAS reflects the three universal domains of household food insecurity that is anxiety about household food insecurity, insufficient quality and insufficient quantity of food supplies. This indicator captures the household's perception about their diet regardless of its nutritional composition [28]. It is supported the idea that households' experiences of food insecurity cause predictable reactions and responses which will be captured and quantified through a survey then summarized into a score. Following [29], the HFIAS is computed as follows:

HFIAS (0-27) = summation of the frequency of occurrence during the past 30 days for the nine-food insecurity-related conditions

$$
\begin{aligned}
\text { HFIAS }(0-27)= & Q 1 a * F 1+Q 2 a * F 2+Q 3 a * F 3 \\
& +Q 4 a * F 4+Q 5 a * F 5+Q 6 a * F 6 \\
& +Q a 7 * F 7+Q 8 a * F 8+Q 9 a * F 9
\end{aligned}
$$

At a household level, a high HFIAS shows that a household is very food insecure, while a low score shows that a household is less food insecure.

\section{Dietary diversity score}

According to FAO's guidelines for assessing household dietary diversity, the population of interest should be chosen prior to the start of the data collection. Because it helps to adapt the questionnaire to the local survey context [25]. A dietary diversity questionnaire can be used to collect information at either household or individual level. The decision on how to collect information depends on the purpose and objective of the survey. If the purpose and objective of the survey are to determine nutrition, assessing household dietary diversity would be the best approach [30]. The dietary diversity score (DDS), is calculated by summing the number of unique food groups consumed during the last 7 days [31]. The value ranges from 0 to 12, in which lowest DDS value signifies higher food insecurity status and vice versa. Even though there is no international consensus on which food groups to include in the scores [32], the DDS denotes 12 food groups. These are cereals; root and tubers; vegetables with tubers; leafy vegetables; fruits; meat, poultry; eggs; fish; pulses/legumes/nuts; milk and milk products; oil/ fats; and sugar/honey. This study considered the 12 food groups in the analysis.

\section{Effect of crop diversification on household food security}

In the analysis of the relation between crop diversification and food security, the study used an ordinary least squares (OLS) regression. Crop diversification index (a continuous variable and food security outcomes DDS and HFIAS are taken as dependent variables (all continuous variables) that, we decided to use OLS regression. According to [33], it is appropriate to use OLS to ascertain influence of a continuous variable on another continuous variable similar to the current study. The OLS model is specified as

$$
Y_{i}=\beta_{0}+\beta_{1} X_{i 1}+\beta_{2} X_{i 2} \cdots+\beta_{n} X_{i n}+e
$$

where $Y_{i}=$ household food security outcome (either DDS or HFIAS), $X_{i 1}=$ crop diversification index, $X_{i 2}=$ sex of household head, $X_{i 3}=$ age of household head (in year), $X_{i 4}=$ education level of household head, $X_{i 5}=$ household size, $X_{i 6}=$ farm land size, ...., $\beta_{0}=$ intercept, $\beta_{1}$ to $\beta_{n}$ are coefficients, and $e$ is the error term. Table 1 shows the description of variables used in our analysis.

\section{Specification of multinomial logit model}

We assessed the determinants of the levels of household food insecurity status using a multinomial logit model. The dependent variable is the discrete or categorical variable represented by household food insecurity access prevalence (HFIAP) status. According to [34], the multinomial is a generalization of the familiar logistic regression, which is used when there are more 
Table 1 Summary of variables included to affect household food security status. Source: Own hypothesis

\begin{tabular}{|c|c|c|c|}
\hline Variables & Variables unit and measurement & Variable class & Sign \\
\hline \multicolumn{4}{|c|}{ Dependent variables } \\
\hline HFIAS & Household Food Insecurity Access Score & Continuous & \\
\hline DDS & Score of food group consumed & Continuous & \\
\hline \multicolumn{4}{|c|}{ Explanatory variables } \\
\hline CDI & Crop diversification index & Continuous & \pm \\
\hline Gender & Household head, $1=$ male, $0=$ female & Discrete & \pm \\
\hline Age & Age of household head in year & Continuous & \pm \\
\hline Edu & Education in year of schooling & Continuous & + \\
\hline Hsize & Size of household in number & Continuous & \pm \\
\hline Lsize & Size of Farm in ha & Continuous & + \\
\hline luse & Access to irrigation land, $\mathrm{Yes}=1, \mathrm{No}=0$ & Continuous & + \\
\hline Cuse & Access to credit, Yes $=1, \mathrm{No}=0$ & Discrete & + \\
\hline Coops & Member to farmers cooperatives, $\mathrm{Yes}=1, \mathrm{No}=0$ & Discrete & + \\
\hline Market & Distance to local market in hour & Continuous & - \\
\hline Nincome & Total annual income in birr & Continuous & + \\
\hline TLU & Livestock holding in TLU & Continuous & + \\
\hline Remit & Remittance, Yes $=1, \mathrm{No}=0$ & Discrete & + \\
\hline Nonfarm & Participation on non-farm activities, $\mathrm{Yes}=1, \mathrm{No}=0$ & Discrete & + \\
\hline extenvisit & Extension contact in days per month & Continuous & + \\
\hline Aginform & Access to agriculture information $\mathrm{Yes}=1, \mathrm{No}=0$ & Discrete & + \\
\hline
\end{tabular}

than two discrete possibilities for the dependent variable. The multinomial logit model generally captures how households' socio-economic and demographic variables affect the probability that a household within the sample exhibit any of the identified possible levels of food insecurity in reference to base outcome. As noted by [35], the use of multinomial logit model is often an important econometric strategy when the choices are unordered. In this case, the test of independence of irrelevant alternatives (IIA) assumption of this model is required. Independence of irrelevant alternatives implies the marginal effect of choosing food secure households as reference households is not affected by the existence of other levels of food insecurity $(p=1$, $2,3)$. In other words, even if households in other levels of food insecurity are taken as a reference point, the outcomes or estimated parameters are expected to be the same. Subsequently, we tested the assumption of IIA and confirmed the suitability of multinomial logit model in the study.

Following [36] the multinomial logistic regression model is defined as follows:

$$
\mathrm{p}_{j i}=\frac{e^{x_{j}^{\prime} \beta j}}{\sum_{j=1}^{m} e^{x ! j \beta j}}=1, \ldots, m
$$

where $p=1$ food secure households; $p=2$ mildly food insecure households; $p=3$ moderately food insecure households and $p=4$ severely food insecure households; $\beta_{j}$ is a vector of coefficients on each of the independent variables $X$. Equation (7) can be normalized to remove indeterminacy in the model by assuming that $\beta_{0}=0$, and the probabilities can be estimated.

The multinomial logistic coefficients are difficult to interpret, and associating the $\beta_{j}$ with the $j$ th outcome is tempting and misleading. Thus, in order to interpret the effects of explanatory variables on the probabilities, marginal effects are usually derived [37]:

$$
\frac{\partial p_{j}}{\partial x_{i}}=p_{j}\left[\beta_{j}-\sum_{k=0}^{j} p_{k \beta_{k}}\right]=p_{j}\left(\beta_{j}-\bar{\beta}\right)
$$

where $P$ is the probability, $X$ is socioeconomic characteristics and other factors, and $\beta$ is a vector of coefficients. The marginal effects measure the expected change in probability of a household fall into particular household food insecurity level with respect to a unit change in an explanatory variable [38]. The signs of the marginal effects and respective coefficients could also be different. The marginal effects depend on the sign and magnitude of all other coefficients. 


\section{Results}

Socio-demographic and socio-economic characteristics

The average age of household-head was 44 years with standard deviation of 10.0. The age of sample household heads ranged from 25 to 68 years. The study revealed that the majority of respondents were within the active labor force. The study also found that two to five persons participated in farming activities for most families.

The mean distance between the sample kebeles and the nearest market place in kilometer is $10.4 \mathrm{~km}$ with a minimum of $1.2 \mathrm{kms}$ and a maximum of $15 \mathrm{kms}$ (Table 2).

The study shows the average family size of household is 7.06 persons with standard deviation of 2.24. About $82.8 \%$ of household heads were unable to read and write. The remaining $17.2 \%$ had attended education level of (primary school 15.4\%, secondary school 1.6 and university or college level $0.5 \%$ ). The average farm experience of household heads is 24.7 years with standard deviation of 8.7.

Regardless of the size of landholding, all the respondents operate farm plots. The landholding size vary from 0.25 to 9 ha. The average landholding is about 2.99 ha with standard deviation of 1.59 ha. In the same token, almost all sample household's own livestock with the mean livestock ownership of 7.5 in Tropical Livestock Unit (TLU) with standard deviation of 4.5 (Table 2).

About $88.25 \%$ of studied households were maleheaded, while the remaining $11.75 \%$ were female-headed households. About $96.87 \%, 1.83 \%$ and $1.13 \%$ were married, divorced, and widow/widower, respectively.

In Sinana District, almost every one is a member of the traditional local institutions such as Idir/Afosha self-help group to cope with funerals, house construction and savings. The study result indicates that the majority (67.97\%) were not members to farmers' cooperatives. Only $12.50 \%$ of the sample households received credit, while $87.50 \%$

\begin{tabular}{lrrrr}
$\begin{array}{l}\text { Table } 2 \text { Household } \\
\text { for continuous variables }(\boldsymbol{n}=\mathbf{3 8 4})\end{array}$ & Mean & St. dev & Min & Max \\
\hline Variables & 44.33 & 9.95 & 25 & 68 \\
\hline Age of household head (in year) & 0.36 & 0.81 & 0 & 4 \\
Education level of hh head (in year) & 7.06 & 2.24 & 2 & 17 \\
Household size (number) & 2.99 & 1.59 & 0 & 9 \\
Farm/land size (in hectares) & 29.34 & 10.19 & 10 & 50 \\
Distance to nearest market (walking & & & & \\
$\quad$ munit) & 6943.19 & 6899.99 & 1200 & 90,000 \\
Total net income (birr) & 1333.33 & 2139.50 & 0 & 9000 \\
Total non/off-farm income (birr) & 7.48 & 4.46 & 0 & 27.017 \\
Livestock holding (TLU) & 1.81 & 1.25 & 0 & 3 \\
Length of food store after harvest (in & & & & 3 \\
$\quad$ month) & & &
\end{tabular}

did not due to various reasons. Out of the non-users, $79.9 \%$ did not used credit due to their religion affiliations and $5.9 \%$ failed to use credit due to fear of repayment (Table 3).

Most respondents $(72.66 \%)$ did not receive any remittance from anywhere, while the remaining $27.34 \%$ received some remittances. The survey results also showed that $95.05 \%$ of the sample households obtained agricultural extension contact (Table 3 ).

In order to triangulate the above results, focused group discussions were made. The discussants revealed that for rural farmers' food availability is highly determined by their own agricultural production and available assets mainly livestock. Moreover, landholding size is crucial for farmers' food security situation. However, focus group participants argued that landholding size in the study area is diminishing mainly due to increasing population size and problem of engaging in the nonfarm sector. Furthermore, participants also indicated that the increased variability of rain fall has triggered and escalated the vulnerability of food production. Consequently, the seasonal variability of rain-fall has pushed

\section{Table 3 Household characteristics for categorical variables $(n=384)$}

\begin{tabular}{|c|c|c|}
\hline Variables & Frequency & Percent \\
\hline \multicolumn{3}{|c|}{ Sex of household head (gender) } \\
\hline Male & 46 & 11.75 \\
\hline Female & 338 & 88.25 \\
\hline \multicolumn{3}{|c|}{ Marital status (Mstatus) } \\
\hline Married & 371 & 96.87 \\
\hline Divorced & 7 & 1.83 \\
\hline Widowed & 5 & 1.31 \\
\hline \multicolumn{3}{|c|}{ Participation on irrigation farming (iuse) } \\
\hline Yes & 354 & 92.19 \\
\hline No & 30 & 7.81 \\
\hline \multicolumn{3}{|c|}{ Use of credit (Cuse) } \\
\hline Yes & 48 & 12.50 \\
\hline No & 336 & 87.50 \\
\hline \multicolumn{3}{|c|}{ Extension agent visit to farm (extenvisit) } \\
\hline Yes & 365 & 95.05 \\
\hline No & 19 & 4.95 \\
\hline \multicolumn{3}{|c|}{ Members to famers cooperative (Coops) } \\
\hline Yes & 261 & 32.03 \\
\hline No & 123 & 67.97 \\
\hline \multicolumn{3}{|c|}{ Remittance (remit) } \\
\hline Yes & 105 & 27.34 \\
\hline No & 279 & 72.66 \\
\hline \multicolumn{3}{|c|}{ Participation on non/off-farm income (nonffarm) } \\
\hline Yes & 132 & 34.62 \\
\hline No & 252 & 65.38 \\
\hline
\end{tabular}


the farmers toward unforeseen margin of vulnerability due to low food production. In other words, unpredicted extreme weather events have impacted on the livelihood assets and threaten the stability of food supply system.

On the issue of crop management particularly, pests and disease control, high incidence of disease and pests cause substantial yield loss, lower grain quality and it interfere with normal physiological development of crops. In this regard, FGD participants has emphasized that the existence of plant disease associated with their wheat farms. Hence, farmers used chemical methods (use of pesticides and herbicides) for wheat farmers in the study areas. Low income households opt to use cultural pest and disease control methods. These methods include: hand weeding and crop rotation.

Similarly, findings from key informant explained that availability of inadequate infrastructures and social services development like road, transportation, communication, electrification, clean water, and agricultural services are the impediments for the sustainability of agricultural production and food security in the study area.

\section{Household food security status \\ Household food insecurity status measured by HFIAS}

The result indicates that $55.73 \%(n=213)$ of households were never worried about having no enough food. In contrast, the remaining $44.2 \%(n=170)$ of surveyed households have experienced problems of both economic and physical access to food at various degree (Table 4).

The severity level depicted that during the last 1 -month period, about $44.56 \%$ of households encountered access problems "rarely"; about 24.87\% "sometimes" and about $30.57 \%$ "often". Furthermore, the finding shows the mean score of HFIAS for the respondents is 11.63 with a standard deviation of 5.16. The finding further showed that $55.87 \%(n=214)$ were most food secure; $24.02 \%(n=92)$ were medium food insecure; and $20.10 \%(n=77)$ were most food insecure. The result implies only $7.32 \%$ of the respondent's food secure, i.e., such households never experience or worried about any form of the food insecurity conditions. In contrast, about $8.07 \%$ of the respondents were severely food insecure, while about $49.96 \%$ and $34.64 \%$ of the respondents were mildly food insecure and moderately food insecure, respectively.

\section{Food security measured by DDS}

The results of the finding on the DDS show respondents were found to have consumed an average of 5.73 food groups with a standard deviation of 1.97 . The minimum DDS value is 2 and the maximum DDS value is 11 . The summary of the DDS in study area is presented in Fig. 2. Further, based on FAO [36] categorization about 13.54\% of the respondents were found to consume less dietary diversity, implying they are more food insecure due to lack of the means to acquire and consume a variety of foods. Those who have medium level of DD account for $50.52 \%$, and about $35.94 \%$ of the respondents have DDS $\geq 8$ that they were food secure and were able to acquire and consume a variety of foods.

\section{Effect of crop diversification on household food security}

We run $F$-statistics and found out that the variables included in the OLS models are significant in influencing the respective dependent variables DDS and HFIAS. The value of $R^{2}$ for the DDS and HFIAS model is $22 \%$ and $15 \%$, respectively. This means that $22 \%$ of the variation in DDS and $15 \%$ of the variation in HFIAS are explained by the variables included in the two respective models. As such CDI, Farm land size, TLU, positively influence DDS, while distance to nearest market and access to remittance have a negative influence on DDS. While CDI, age and education have a negative influence on HFIAS, the

Table 4 Distribution of households by HFIAS condition

\begin{tabular}{|c|c|c|c|c|c|c|}
\hline \multirow[t]{2}{*}{ HFIAS condition } & \multicolumn{2}{|c|}{ Rarely } & \multicolumn{2}{|c|}{ Sometimes } & \multicolumn{2}{|c|}{ Often } \\
\hline & $N$ & $\%$ & $N$ & $\%$ & $N$ & $\%$ \\
\hline Worry about food & 136 & 80.00 & 19 & 11.78 & 15 & 8.82 \\
\hline Unable to eat preferred foods & 195 & 53.72 & 114 & 31.40 & 54 & 14.88 \\
\hline Eat just a few kinds of foods & 92 & 30.46 & 84 & 27.81 & 126 & 41.72 \\
\hline Eat foods they really do not want eat & 41 & 11.40 & 87 & 23.77 & 238 & 65.03 \\
\hline Eat a smaller meal & 99 & 51.03 & 63 & 32.47 & 32 & 16.49 \\
\hline Eat fewer meals in a day & 75 & 68.81 & 19 & 17.43 & 15 & 13.76 \\
\hline No food of any kind in the household & 38 & 82.61 & 5 & 10.87 & 3 & 6.52 \\
\hline Go to sleep hungry & 16 & 88.89 & 2 & 11.11 & 0 & 0 \\
\hline Go a whole day and night without eating & 12 & 100 & 0 & 0 & 0 & 0 \\
\hline
\end{tabular}

Clues to the severity status: (1) Rarely (once or twice in the past 4 weeks); (2) Sometimes (three to ten times in the past 4 weeks); (3) Often (more than ten times in the past 4 weeks) 


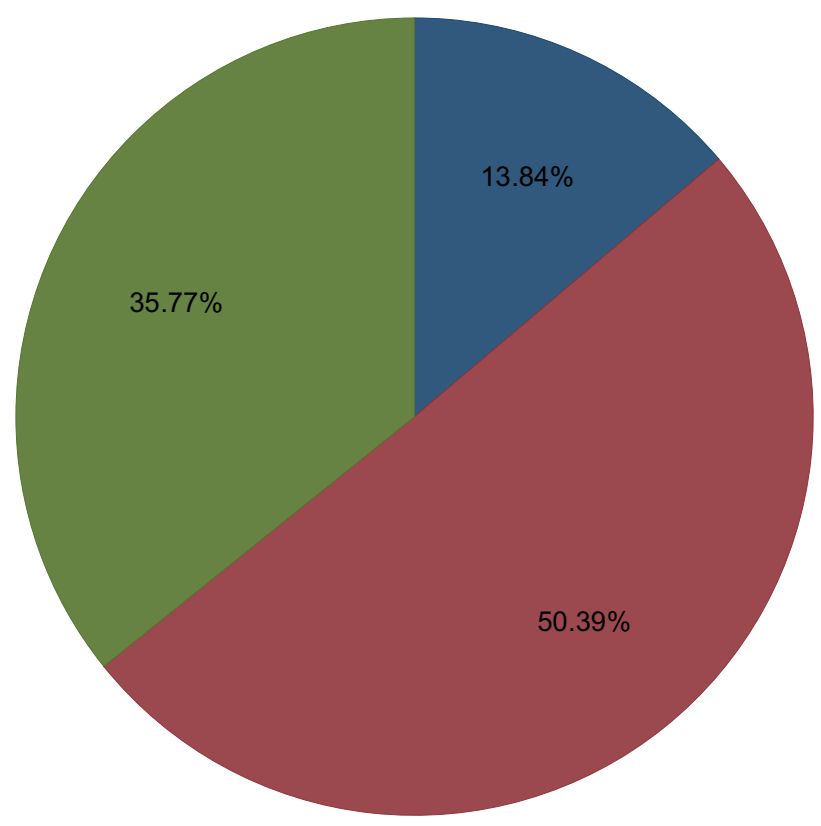

\section{Low Dietary Diversity Score} High Dietary Diversity Score

Fig. 2 Dietary diversity status of study site ( Source: Field survey 2019)

distance to nearest market and access to remittance positively influence HFIAS (Table 5). Crop diversification as measured by the index has a positive influence on DDS and a negative influence on HFIAS. The coefficient of CDI is also significant at $1 \%$ and shows a positive influence on household DDS. Oppositely, the coefficient of CDI is significant at $1 \%$ and shows a negative influence on HFIAS.

\section{Determinants to household food insecurity}

We employed multinomial logistic analysis to determine factors affecting household food security phenomenon. We hypothesized independent variables were expected to affect the household food security. Before running the econometric model, the independent variables were tested for the presence of multicollinearity. The calculated VIF values are all less than 10 (the cutoff point) which indicated that multicollinearity is not a serious problem. The goodness of fit in multinomial logistic regression analysis was checked and the likelihood ratio test statistics indicated by the Chi-square statistics is highly significant (significance $=0.0000$ ) suggesting strong explanatory power of the model. The value of $R^{2}$ for the multinomial logistic regression analysis is $12 \%$. The result of the multinomial logit analysis of the hypothesized independent variables which were expected to affect the household food security are provided in Table 6.

Age of household head The result of the model depicted that the age of the household head was negatively related to household food security compared to base category, which is mildly food insecure. Keeping other factors constant, food security condition decreases by $0.50 \%$ when age of the household head increases by 1 year.

Marital status Marital status of the household head positively affected household food security when compared to base category. The model predicted that the likelihood of household being food secure increases by a factor of 0.121 when household is married.

Education level of household head The result of this study indicates that when comparing with the base category, household head education level positively affected household food security. From the model result, the marginal effect reveals that the literacy level of household head increase likelihoods of household food security by $7.9 \%$.

Access to irrigation farming Participating in irrigation is another important factor in determining house- 
Table 5 OLS regression of the effects of crop diversification on household food security

\begin{tabular}{|c|c|c|c|c|}
\hline \multirow[t]{2}{*}{ Variables } & \multicolumn{2}{|l|}{ DDS } & \multicolumn{2}{|l|}{ HFIAS } \\
\hline & Coef & $P>t$ & Coef & $P>t$ \\
\hline Crop Diversification Index (number) & 1.01 & $0.00^{*}$ & -1.48 & $0.00^{*}$ \\
\hline Sex of household head (male/female) & -0.27 & 0.36 & 0.02 & 0.98 \\
\hline Age of household head (year) & 0.01 & 0.32 & -0.05 & $0.07^{* * *}$ \\
\hline Edu of household head (year of schooling) & 0.14 & 0.25 & -0.79 & $0.02^{* *}$ \\
\hline Household size (number) & -0.05 & 0.32 & 0.18 & 0.16 \\
\hline Farm land size (in hectares) & 0.14 & $0.05^{* *}$ & -0.29 & 0.13 \\
\hline Irrigation farming (yes/no) & 0.63 & 0.10 & -0.35 & 0.74 \\
\hline Access to credit (yes/no) & 0.00 & 0.99 & -0.10 & 0.90 \\
\hline Membership to famers cooperatives (yes/no) & 0.10 & 0.60 & -0.25 & 0.67 \\
\hline Distance to the nearest market (walking $\mathrm{min} / \mathrm{h}$ ) & -0.03 & $0.00^{*}$ & 0.06 & $0.02^{* *}$ \\
\hline Total annual net income (birr) & 0.18 & 0.18 & 0.83 & 0.12 \\
\hline Livestock ownership in TLU & 0.06 & $0.01^{* *}$ & 0.03 & 0.64 \\
\hline Access to remittance (birr) & -0.68 & $0.01^{* *}$ & 2.82 & $0.00^{*}$ \\
\hline Participation on off/non-farm activities (yes/no) & 0.14 & 0.56 & -0.21 & 0.74 \\
\hline _cons & 4.99 & 0.00 & 7.11 & 0.00 \\
\hline$R^{2}$ & 22.0 & & 15.0 & \\
\hline Adjusted $R^{2}$ & 19.01 & & 11.7 & \\
\hline F & 1.8 & & 4.9 & \\
\hline N & 383 & & 383 & \\
\hline
\end{tabular}

* ,**, and *** indicate statistical significance at 1,5, and 10\% probability levels, respectively

Table 6 Multinomial logit model

\begin{tabular}{|c|c|c|c|c|c|c|c|c|c|}
\hline \multirow[t]{2}{*}{ Variables } & \multicolumn{3}{|c|}{ Food secure } & \multicolumn{3}{|c|}{ Moderately food insecure } & \multicolumn{3}{|c|}{ Severely food insecure } \\
\hline & Coef & Std.err & M.eff & Coef & St.er & M.eff & Coef & St.err & M.eff \\
\hline Gender & 0.645 & 0.523 & 0.079 & 0.281 & 0.465 & 0.008 & 0.271 & 0.509 & 0.002 \\
\hline Age & $-0.029^{* * *}$ & 0.018 & -0.005 & 0.007 & 0.017 & 0.002 & 0.020 & 0.020 & 0.003 \\
\hline Mstatus & $1.332^{* * *}$ & 0.781 & 0.121 & 1.264 & 0.781 & 0.113 & 1.013 & 0.832 & 0.030 \\
\hline Edu & $0.496^{* *}$ & 0.225 & 0.079 & 0.079 & 0.179 & 0.034 & 0.003 & 0.222 & 0.011 \\
\hline Hsize & -0.011 & 0.075 & -0.006 & 0.070 & 0.073 & 0.010 & 0.056 & 0.088 & 0.004 \\
\hline Lsize & 0.068 & 0.116 & 0.011 & 0.047 & 0.111 & 0.008 & -0.085 & 0.133 & -0.013 \\
\hline luse & -0.512 & 0.546 & -0.012 & $-1.469^{* *}$ & 0.817 & -0.217 & -0.093 & 0.895 & 0.059 \\
\hline Cuse & $0.886^{* *}$ & 0.441 & 0.101 & 0.293 & 0.466 & -0.020 & 0.787 & 0.543 & 0.054 \\
\hline Coops & 0.226 & 0.380 & 0.059 & -0.461 & 0.333 & -0.079 & -0.174 & 0.379 & -0.008 \\
\hline Market & 0.026 & 0.017 & 0.002 & -0.003 & 0.016 & -0.005 & $0.091^{*}$ & 0.021 & 0.010 \\
\hline Nincome & 0.193 & 0.206 & 0.061 & -0.219 & 0.213 & -0.014 & $-0.800^{*}$ & 0.274 & -0.088 \\
\hline TLU & 0.013 & 0.036 & 0.005 & $-0.082^{* *}$ & 0.039 & -0.015 & 0.028 & 0.039 & 0.006 \\
\hline Remit & -0.338 & 0.449 & -0.115 & $0.912^{* *}$ & 0.394 & 0.131 & 0.897 & 0.459 & 0.076 \\
\hline Nonfarm & -0.367 & 0.402 & -0.044 & -0.464 & 0.373 & -0.072 & 0.294 & 0.448 & 0.061 \\
\hline Prodpyear & 0.663 & 0.542 & 0.072 & 0.697 & 0.488 & 0.087 & -0.019 & 0.516 & -0.047 \\
\hline agrinform & 0.257 & 0.450 & -0.015 & -0.468 & 0.395 & 0.098 & $-0.850^{* *}$ & 0.437 & 0.040 \\
\hline CDI & -0.472 & 0.312 & -0.029 & $0.818^{*}$ & 0.304 & -0.025 & $0.689^{* *}$ & 0.355 & -0.066 \\
\hline _cons & -2.620 & 1.627 & & -2.432 & 1.524 & & -5.551 & 1.708 & \\
\hline \multirow{4}{*}{\multicolumn{3}{|c|}{ Log likelihood = - 440.689}} & & & 384 & \\
\hline & & & \multicolumn{4}{|c|}{$\operatorname{LRChi}{ }^{2}[49]=$} & & 122.17 & \\
\hline & & & \multicolumn{4}{|c|}{ Prob $>C h i^{2}=$} & & 0.0000 & \\
\hline & & & \multicolumn{4}{|c|}{ Pseudo $R^{2}=$} & & 0.1217 & \\
\hline
\end{tabular}

\footnotetext{
${ }^{*},{ }^{* *}$, and ${ }^{* * *}$ indicate statistical significance at 1,5 , and $10 \%$ probability levels, respectively
} 
hold food security. In study area merely about $21.7 \%$ of households participate in irrigation farming despite optimistic view of the focus group discussants and key informants who outlined the presence of some opportunities for irrigation-based farming. The model result indicated that there is a negative association between irrigation and moderately food insecurity status of the studied households. Irrigation negatively and significantly affected moderately food insecurity. All other things remain constant, the marginal effect of the model predicted that participation in irrigation farming decreases moderately food insecurity by a factor of 0.012 .

Access to credit Use of credit was also one of determinant factors that affect household food security. Credit utilization positively determines household food security. The marginal effect shows, other things being constant, the likelihood of household being food secure increase by $10.10 \%$ when household used credit.

Distance to the nearest market In this study, distance to the nearest market was found to be the most important predictor variable affecting household food security. From the results we see that comparing with the base category, distance to the nearest market. The marginal effect indicates that, the likelihoods of the household being severely food insecure decreases by $1.00 \%$ as distance to the nearest market increases by one-minute walking.

Total the net income There is a negative relationship between total net income of the households and their food security conditions when comparing with the base category. The marginal effect shows other things being constant, the likelihood of household being severely food insecure decrease by $8.80 \%$ as income of household increase by one birr.

Livestock own in TLU Livestock own in TLU is significant at 5\% probability level and influences negatively the moderate food insecure category. Other things remain constant, the marginal effect of the model shows, with a one-unit increase in livestock holding in TLU decreases the household's tendency to fall in moderately food insecure by $1.50 \%$.

Income received through gift (aid) and remittance Income received through gift (aid) and remittance positively affected moderately and severely food insecurity categories. The marginal effect of the model shows, with a onebirr increase in household remittance, the household's tendency to fall in moderately food insecure increases by $13.1 \%$ ceteris paribus.
Access to agriculture information Access to agriculture information is significant at $5 \%$ probability level and influences negatively the severely food insecure category. Holding other variables in the model constant, the marginal effect of the model shows, access to agriculture information decreases the household's tendency to fall in severely food insecure by $4.00 \%$.

Crop diversification Crop diversification index negatively affects moderately and severely food insecure categories in study area. The marginal effect shows, other things being constant, the likelihood of household being fall in the moderately and severely food insecure categories decreases by $2.50 \%$ and $6.60 \%$, respectively, as crop diversification index increases by one unit.

\section{Discussion}

This study assessed effect of crop diversification on household food security and determinants to household food security in Ethiopia. In this study, the average family size of 7.06 persons is by far larger than the national average of 4.6 persons per household [39, 40]. The findings of this study revealed that households with higher crop diversification intensities are more likely to have diversity in terms of food crops that can be consumed within the household thus justifying the positive relationship. This implies crop diversification improves dietary diversification in Sinana District.

The result also showed crop diversification reduces the severity of food insecurity in Sinana District. It suggests that households with higher crop diversification intensities are more likely to diversity in terms of food crops. This indicates crop diversification improves dietary diversification in study area. The negative relationship between CDI and HFIAS implies that households with higher crop diversification intensities are more food secure as compared to those with relatively lower crop diversification intensities. The possible clarification of this result could be that households that engage in multiple cropping are diversifying the possible risk of a particular crop failure in a season. Households that cultivate multiple crops are better assured of food availability and access than household who practice mono cropping. For instance, in a season, where one particular crop fails to give much yield, other crops may be better off on which farmers may rely on for survival. Thus, farmers who intensify crop diversification are better off than their counterparts, because diversification is positively related to dietary diversification and negatively related to food insecurity. This is mainly attributed to the benefits of crop diversification to include, raising farm productivity, income, and reducing production and price risks. Our finding concurs with previous similar studies, 
which demonstrated positive relationship between crop diversification and food security of the household [16, 41, 42]. For example, Jones and others [43] found that farm production diversity was consistently and positively associated with household dietary diversity. More generally, Agriculture, crop diversification in particular can offer opportunities for soil and land use management, and biomass production [44]. Others, for instance [45, 46], found that crop diversification positively influence participation in insurance schemes that help reduce farmers' risk from weather and price shocks. Further, the merits of crop diversification in improving food security can be manifested through better management of price and production risks [47]. This is probably due to growing more than one crop species in a single season gives the farmers more options. It in turn helps the farmers to manage price and production risks better as compared to less diversified farming enterprises.

Although crop diversification was positively associated with household food security, several other factors were found to be as or more important in increasing household food security. The age of household head negatively associated with household food security. However, this finding contradicts our expectation (Table 6). The possible reason could be as the age of the person increase, one may lose job and/or could not participate in other income generating activities. Furthermore, elderly farmers do not have the required labor force to produce more food crops compared to the young people. This is in line with findings from other studies [48]. Previous studies argued that younger farmers are more likely to be food insecure than the older farmer due to better capital accumulation of the later [49].

Marital status affected household food security. However, being married in itself is not an assurance to escape from the risk of food insecurity. This might imply that a household headed by married parents support each other all their way to food sufficiency in contrast to a single or widow household who often lacks mutual support. It is related to factors such household size, level of income household, among others that affect food security status associate to marital status. Consonant with our study [50], found that marital status has positive relation with household food security.

On average, large number of farmers did not attend the minimum required educational level. They may not understand adequately written agricultural instructions and information provided by the extension workers. The finding of the study indicates that education and farm experiences significantly affect household food security in study area. The possible reason is better educated household heads are more likely to secure food than uneducated (illiterate) household heads. This is due to the fact that the contribution of education to work efficiency, competency, diversify income and becoming visionary in creating conducive environment is positive. It has had a spillover effect on the education of dependents and long-term target to ensure better living condition than illiterate ones. The result coincides with the theoretical evidences that educational improvement could lead on reducing the matter of food insecurity. Studies [50-52] in Dire Dawa, Addis Ababa and elsewhere supported our expectation that a household head with higher education level increases the chance of household achieving food security.

Participation in irrigation farming affected household food security. This implies that irrigation enables households to grow food crops more than once a year, hence increased production, income and food availability of the household. So, it overcomes of food insufficiency in dry or food shortage circumstance and normal seasons. This result is similar with the result of [53].

Credit is a source of capital that boosts the capacity of rural households to purchase yield enhancing agricultural inputs and has remained to be a shortcoming for poorer households in intensifying the farming sector. Thus, the influential association between use of credit and household food security may be due to the fact that households that use credit has opportunity to purchase agricultural input and allow households that cultivate larger land areas produce enough food to feed their household members and also produce surplus to sell and increase their household income. Similar study found out that credit is important to invest on activities that generate income for farm households. The households can purchase agricultural inputs such as improved seeds, fertilizer, and fattening and selling livestock to earn additional income. Farm households who have access to credit could increase their production and other possibilities and hence escape food shortage [54].

Market distance refers to the number of kilometers farmers have to travel to reach the next marketplace to sell their produce. Farmers who live near to the market places are more food secure than their counter part. Previous studies $[55,56]$ in Ethiopia revealed that market access has negative and significant effect on household food security.

The result shows that those households who possess large income are more likely classified as food secure. The result corresponds with the prior expectation, and therefore, the possible explanation is that income determines purchasing power of the household with the prevailing price in order that those households having higher income are less likely to become food insecure than low income households. This finding is consistent with a study reported from Ethiopia, Ghana and South Africa [57-59]. 
The positive relationship between livestock owned and household food security is explained by the fact that livestock size being a proxy for rural household resource endowment and asset accumulation. As such, those sample respondents with large livestock size have better chance to earn more income. This demonstrated that as the livestock resources increases, the probability of the household to secure food increases. In support our finding [60], found out that households with more livestock ownership were less likely to be food insecure in rural Ethiopia. Similarly $[61,62]$, demonstrated that livestock ownership and sales contributed to the household food security through increasing in food consumption expenditure and dietary diversity.

The positive relationship between household food security and remittance is due to the fact that an increase in remittance and gifts income will have a positive effect, because the change in income will cause constant change in expenditure. Thus, the income received from remittance and gifts increases the income in order that capacity of the households to consume more will increase. In support of this findings [63, 64], revealed that households with remittances had better food consumption, minimized vulnerability, and better food security than the households that did not have remittances, but contended that the benefit to solve food insecurity was temporary. Further, the result is in line with the findings of [65]. They argued that remittance contributes to economic development and protects basic human rights, where the aid fills a severe food gap. In contrast, a study conducted in Niger by [66] revealed that food aid influences negatively and significantly the household food security. Similarly, a study done by $[49,67]$ in Ethiopia suggests that food aid displaces domestic production and commercial trade by depressing prices in the recipient countries; it affects the labor supply negatively, enhances market imperfections and information asymmetries, and this, in turn, affects economic development.

Based on household food insecurity access prevalence, our study is in line with that of [43] who found out that more diverse production system can also lead to more diverse household diets in Malawi. Regarding the remoteness and the poor quality of infrastructure in our study areas, the household food access depends on what the household often produces. In other words, the households' food diet is closely linked to their experiences of crops production. Household may choose to diversify crops because of poor infrastructure [68]. This would help them to obtain the kind of food they need at the local level. Concurrent results were reported from Kenya and Tanzania by [69] who found that in, the number of crops grown by a household has associated with the dietary variety of the household.

\section{Conclusion and recommendation}

The main aim of this study was to examine the effect of crop diversification on household food security and analyze socioeconomic factors affecting food security. Crop diversification was measured by Herfindahl-Hirschman Index, while food security was measured by the household food insecurity access scale and household dietary diversity. Crop diversification index negatively influenced HFIAS and positively influenced DDS. Notwithstanding, the HFIAS multinomial regression model revealed that higher education levels of household head, age of household head, participating in irrigation farming, livestock holding in TLU, access to agriculture information and crop diversification index positively influenced household food security conditions. On the other hand, distance to the nearest market negatively affected household food security.

We tend to conclude that rural households with diversified cropping systems were more secure in terms of food supplies and income and hence they are able to meet for the food requirement of their households. This suggests that crop diversification potentially improves food security through improving food security stocks in terms of quantity and variety and also in improving income through sale of crop produced from a variety of crops grown which in turn, improve consumption patterns of the household. Therefore, District Agriculture office needs to intensify the promotion of crop diversification in rural farming with particular focus to less diversified households so as to improve the food security status of the rural people.

Considering the fact that a larger number of households kept livestock based as a tradition, increasing the number of livestock kept as a means of boosting income should be prioritized. To this end, provision of support towards training and animal husbandry and pastureland development may enhance the livestock production and productivity and hence increase food security.

In tandem, any efforts geared towards improving household food and nutritional security in the long run should be centered on the development of irrigation farming as one of the key determinants of food security. Precisely to say irrigation farming tremendously increases household food security status. Thus, to increase food security, measures that would improve irrigation farming should be introduced.

In addition, household educational level immensely contributed to the status of food security. Therefore, any interventions meant to support rural households by governmental and non-governmental organizations need to emphasize capacity building through training and informal/alternative basic education. Informal education and training could create opportunities for 
gaining knowledge on nutritious food production and consumption and sharing of experiences among farmers. Thus, empowerment of farmers through adequate training and informal education has the potential to improve household food security condition.

Finally, households' distance to nearest market was significantly and negatively associated with food security. Thus, improving rural infrastructural development such as roads and market center and market information contribute to enhance food security status of rural residents.

\begin{abstract}
Abbreviations
CSA: Central Statistical Agency; CDI: Crop Diversification Index; DA: Development agents; DDS: Dietary Diversity Score; EIU: Economist Intelligence Unit; FAO: Food and Agriculture Organization of the United Nations; FGDs: Focus group discussions; GFSI: Global Food Security Index; HFIAP: Household food insecurity access prevalence; HFIAS: Household food insecurity access scale; HHI: Herfindahl-Hirschman Index; HI: Herfindahl Index; IIA: Independence of irrelevant alternatives; Klls: Key informant interviews; OLS: Ordinary least square; TLU: Total livestock unit; VIF: Variance inflation factors.
\end{abstract}

\section{Acknowledgements}

The authors acknowledge respondent farmers and data collectors. Addis Ababa University, Madda Walabu University were also acknowledged for their financial and logistic support in accomplishing this paper. The authors also would like to extend their deep thanks to all the contributors of this study namely local administrators, and development agent workers who took part in the survey.

\section{Authors' contributions}

DDM designed the study, collected the data, performed the analysis, and developed the manuscript. DTD and AST contributed to the research design and analysis, reviewed and made editorial comments on the draft manuscript. All authors read and approved the final manuscript.

\section{Funding}

This research was supported and funding by Addis Ababa University.

\section{Availability of data and materials}

The authors want to declare that they can submit the data at whatever time based on your request. The datasets used and/or analyzed during the current study will be available from the corresponding author on reasonable request.

\section{Ethics approval and consent to participate}

The researchers have obtained a support letter from Addis Ababa University. The letter was submitted to Bale Zone Agriculture and Natural Resource Office and obtained consent. Then, the zonal offices have written an official letter to Sinana District Agriculture and Natural Resource Office, where the study was conducted. Informed consents were also obtained from the households, discussants, and informants before data collection in conformity with anonymity of the study participants.

\section{Consent for publication}

Not applicable.

\section{Competing interests}

The authors declare they have no competing interests.

Received: 22 May 2020 Accepted: 27 November 2020 Published online: 28 February 2021

\section{References}

1. Joshi PK, Ashok G, Birthal PS, Tewari L. Agriculture diversification in South Asia: patterns, determinants, and policy implications (No. 57), Washington, D.C. 2006.

2. Mandal R, Bezbaruah MP. Diversification of cropping pattern: its determinants and role in flood affected agriculture of assam plains. Indian J Agric Econ. 2013;68(2):169-81.

3. Kalkuhl M, Kornher L, Kozicka, M, Boulanger P, Torero M. Long-term drivers of food and nutrition security. FOODSECURE working paper no. 06. 2013. The Hague: LEI Wageningen UR.

4. Pieters $\mathrm{H}$, Guariso A, Vandeplas A. Conceptual framework for the analysis of the determinants of food and nutrition security FOODSECURE Working paper no. 13. The Hague: LEI Wageningen UR. 2013.

5. FAO (Food and Agriculture Organization). Declaration on world food security. Rome: World Food Summit; 1996.

6. Babatunde RO, Qaim M. Impact of off-farm income on food security and nutrition in Nigeria. Food Policy. 2010;35(4):303-11.

7. FAO. The state of food security and nutrition in the world: building climate resilience for food security and nutrition. Rome, 2018. http://www. fao.org/3/19553EN/i9553en.pdf. Accessed Dec 2019.

8. Belfield S, Brown C. Field crop manual: wheat a guide to upland production in Cambodia. 1st ed. State of New South Wales: Department of Primary Industries; 2008.

9. Berry EM, Dernini S, Burlingame B, Meybeck A, Conforti P. Food security and sustainability: can one exist without the other? Public Health Nutr. 2015;18:2293-302.

10. Central Statistical Authority (CSA). Ethiopia demographic and health survey. Addis Ababa, Ethiopia. 2016. https://dhsprogram.com/pubs/pdf/ FR328/FR328.pdf.

11. Endalew $B$, Muche M, Tadesse $S$. Assessment of food security in Ethiopia: a review. Asian J Agric Sci. 2015;9:55-68.

12. Economist Intelligence Unit (EIU). Global Food Security Index. New York, USA. https://foodsecurityindex.eiu.com/Country/Details\#Ethiopia. 2018.

13. EDHS (Ethiopia Demographic and Health Survey). Ethiopia demographic and health survey 2011. Addis Ababa, Ethiopia.

14. Devereux, S. Food insecurity in Ethiopia: a discussion paper for DFID. Addis Ababa, Ethiopia. 2000. https://www.researchgate.net/publicatio n/50200941 Accessed Mar 2019.

15. BZADO (Bale Zone Agricultural Development Office). Annual report 2017. Bale Zone Agricultural Development Office (Unpublished). Bale-Robe, Ethiopia

16. Njeru EM. Crop diversification: a potential strategy to mitigate food insecurity by smallholders in sub-Saharan Africa. J Agric Food Syst Community Dev. 2013;3(4):63-9. https://doi.org/10.5304/jafscd.2013.034.006.

17. Makate C, Wang R, Makate M, Mango N. Crop diversification and livelihoods of smallholder farmers in Zimbabwe: adaptive management for environmental change. SpringerPlus. 2016;5(1):1-18. https://doi. org/10.1186/s40064-016-2802-4.

18. Pellegrini L, Tasciotti L. Crop diversification, dietary diversity and agricultural income: empirical evidence from eight developing countries. Can J Dev Stud/Rev Can d'études du développement. 2014;35:211-27.

19. Michlera JD, Josephson AL. To specialize or diversify: agricultural diversity and poverty dynamics in Ethiopia. World Dev. 2017:89:214-26.

20. Di Falco S, Chavas J-P, Smale M. Farmer management of production risk on degraded lands: the role of wheat variety diversity in the Tigray Region, Ethiopia. Agric Econ. 2007;36(2):147-56. https://doi.org/10.111 1/j.1574-0862.2007.00194.x.

21. Bureau of Finance and Economic Development (BOFED). Physical and socio-economic profile of Oromiya. The National Regional Government of Oromiya. Development-Regional Data and Information Core Process. Addis Ababa, Ethiopia. 2009.

22. Creswell JW, Plano Clark VL. Designing and conducting mixed methods research. 2nd ed. Thousand Oaks: Sage; 2011.

23. Morse JM, Niehaus L. Mixed methods design: principles and procedures. Walnut Creek: Left Coast Press; 2009.

24. Yamane T. Statistics, an introductory analysis. 2nd ed. New York: Harper and Row; 1967.

25. Sichoongwe K, Laqrene M, Ng'ng'ola D, Temb G. The determinants and extent of crop diversification among smallholder farmers. A case study of Southern Province, Zambia, Malawi Strategy Support Program, Working Papers 05, Washington DC. 2014. 
26. Muhammad BK, Schilizzi S, Pandit R. The determinants of rural household food security in the Punjab, Pakistan: an econometric analysis. Working Paper 1203, 2012. School of Agricultural and Resource Economics, University of Western Australia, Crawley, Australia.

27. Ballard TJ, Kepple AW, Cafiero C. The food insecurity experience scale: development of a global standard for monitoring hunger worldwide. Technical paper. 2013. Rome, FAO. http://www.fao.org/economic/ess/essfs/voices/en/.

28. Deitchler M, Ballard T, Swindale A, Coates J. Introducing a simple measure of household hunger for cross-cultural use. Washington, DC: Food and Nutrition Technical Assistance; 2011.

29. Mango N, Zamasiya B, Makate C, Nyikahadzoi K, Siziba S. Factors infuencing household food security among smallholder farmers in the Mudzi district of Zimbabwe. Dev S Afr. 2014;31(4):625-40. https://doi. org/10.1080/0376835X.2014.911694.

30. Coates J, Swindale A, Bilinsky P. Household Food Insecurity Access Scale (HFIAS) for measurement of food access: indicator guide. Washington, DC: Food and Nutrition Technical Assistance Project, Academy for Educational Development; 2007

31. FAO. Food insecurity in the World: addressing food insecurity in protracted crises 2010. Food and Agriculture Organization of the United Nations, Rome. http://www.fao.org/docrep/013/i1683e/i1683e.pdf. Accessed 10 July 2019.

32. Gero C, Alberto Z, Raka B. Towards better measurement of household food security: harmonizing indicators and the role of household surveys. Glob Food Secur. 2013;2(1):30-40. https://doi.org/10.1016/j. gfs.2012.11.006.

33. FAO. The state of food insecurity in the world: addressing food insecurity in protracted crises. Rome: United Nations'Food and Agricultural Organization; 2010.

34. Isik-Dikmelik A. Trade reforms and welfare: an ex-post decomposition of income in Vietnam. World Bank Policy research working paper. Washington DC: World Bank; 2006.

35. Rose D, Chariton KE. Quantitative indicators from food expenditure survey can be used to target the food insecure in South Africa. J Nutr. 2002;132:3235-42.

36. Bhat CR. Random utility-based discrete models for travel demand analysis. In: Goulias KG, editor. Transportation systems planning: methods and applications. Boca Raton: CRC Press; 2003. p. 10-30.

37. Greene WH. Econometric analysis. 6th ed. New Jersey: Prentice-Hall; 2008.

38. Greene WH. Econometric analysis. 7th ed. New Jersey: Prentice-Hall; 2012.

39. FAO. Report on use of the household food insecurity access scale and household dietary diversity score in two survey rounds in Manica and Sofala Provinces, Mozambique, 2006-2007; 2008a. http://www.fao. org/fleadmin/user_upload/eufao-fsi4dm/doc-training/moz_diet.pdf. Accessed Feb 2020.

40. EDHS (Ethiopia Demographic and Health Survey). Ethiopia demographic and health survey 2012, Addis Ababa, Ethiopia.

41. CSA. Agricultural sample survey 2013/2014 (2006 E.C.): Volume IV—report on land utilization (Private peasant holdings Meher season). 2014C. Statistical Bulletin number 446. Central Statistical Agency, Addis Ababa, Ethiopia.

42. Ame Ch, Aung T, Stijn S. Assessment of household food security through crop diversification in Natmauk Township, Magway Region, Myanmar. In: Conference on International Research on Food Security, Natural Resource Management and Rural Development organised by the University of Natural Resources and Life Sciences (BOKU Vienna), Austria (September 18-21, 2016).

43. Jones AD, Shrinivas A, Bezner-kerr R. Farm production diversity is associated with greater household dietary diversity in Malawi: findings from nationally representative data. Food Policy. 2014;46:1-12. https://doi. org/10.1016/j.foodpol.02.001.

44. Nelson GC. Agriculture and climate change: an agenda for negotiation inCopenhagen. 2020 focus brief 16. Washington, DC: International Food Policy Research Institute; 2009

45. Santeramo FG, Goodwin BK, Adinolfi F, Capitanio F. Farmer participation, entry and exit decisions in the Italian crop insurance programme. J Agric Econ. 2016;67(3):639-57.

46. Fan S. "Leveraging smallholder agriculture for development," speech given at the Chicago Council on Global Affairs Symposium on Global
Agriculture and Food Security, "Progress to Date and Strategies for Success,"Washington, DC, May 14, 2011.

47. Baumgärtner S, Quaas MF. Managing increasing environmental risks through agro-biodiversity and agri-environmental policies. Working paper series in economics 2008, University of Luneburg.

48. Basher CB, Reardon T, Webb P. Nonfarm income diversification and household livelihood strategies in rural Africa: concepts, dynamics, and policy implications. Food Policy. 2010;26(4):315-31.

49. Moroda G, Tolossa D, Semie N. Food insecurity of rural households in Boset district of Ethiopia: a suite of indicators analysis. Agric Food Secur. 2018;7:65. https://doi.org/10.1186/s40066-018-0217-x.

50. Aschalew F, Ayalneh B. Determinants and dimensions of household food insecurity in Dire Dawa Town, Ethiopia. East Afr J Sci. 2009;3(2):134-41.

51. Ejigayhu S, Abdi-Khalil E. Determinants of food insecurity in Addis Ababa City, Ethiopia. J Econ Sustain Dev. 2012;3(3). www.iiste.org ISSN 2222-1700 (Paper) ISSN 2222-2855.

52. De Cock N, D'Haese M, Vink N, Van Rooyen CJ, Staelens L, Schönfeldt HC. Food security in rural areas of Limpopo province. S Afr Food Secur. 2013;5(2):269-82.

53. Tizita $D$, Ayele T, Fitsum $H$. The effect of small-scale irrigation on household food security in Bona-Zuria Woreda, Sidama Zone, Southern Ethiopia. 2017. A Thesis Submitted to The School of Environment, Gender and Development Studies.

54. Alemu T, Tsehay S. Agricultural technology adoption, commercialization and food security linkage: micro evidence from Boricha Wereda, Sidama Zone SNNPR Ethiopia. 2018. A thesis submitted to College of Development Studies, Center for Food Security in Partial Fulfillment of The Requirements for The Degree of Master of Science in Food Security and Development Studies.

55. Regass N. A small holder farmers coping strategies to household food insecurity and hunger in Sidama Woreda Southern Ethiopia. EJESM. 2011;4(1):39-40.

56. Bedeke SB. Food insecurity and copping strategies: a perspective from Kersa district, East Hararghe Ethiopia. Food Sci Qual Manage. 2012;5:19-26.

57. Motbainor A, Worku A, Kumie A. Level and determinants of food insecurity in East and West Gojjam zones of Amhara Region, Ethiopia: a community based comparative cross-sectional study. BMC Public Health. 2016;16:503. https://doi.org/10.1186/s12889-016-3186-7.

58. Aidoo R, Mensah JO, Tuffour T. Determinants of household food security in the Sekyere Afram plains district in Ghana. Kumasi: Dept of Agricultural Economics, agri-business and extensions, Kwame Nkrumah University of Science and Technology; 2013.

59. Sekhampu T. Determinants of the food security status of households receiving government grants in Kwakwatsi South Africa. Mediterranean J Soc Sci. 2013;4(1):147-53.

60. Demeke AB, Keil A, Zeller M. Using panel data to estimate the effect of rainfall shocks on smallholder's food security and vulnerability in rural Ethiopia. Clim Chang. 2011;108:185-206.

61. Jodlowski M, Winter-Nelson A, Baylis K, Goldsmith PD. Milk in the data: food security impacts from a livestock field experiment in Zambia. World Dev. 2016;77:99-114.

62. Kafle K, Winter-Nelson A, Goldsmith P. Do 25 cents more per day make a difference? The impact of livestock transfers and development in rural Zambia. Food Policy. 2016;63:62-72.

63. Generoso R. How do rainfall variability, food security and remittances interact? The case of rural Mali. Ecol Econ. 2015;114:188-98.

64. Thow MA, Fanzo J, Negin J. A systematic review of the effect of remittances on diet and nutrition. Food Nutr Bull. 2016;37:42-64.

65. Barrett BC, Maxwell DG. Food aid after fifty years-recasting its role. London: Routledge; 2005

66. Seydou Z, Liu Y, Baohui S. Factors influencing household food security in West Africa: the case of southern Niger. Sustainability. 2014;6:1191-202. https://doi.org/10.3390/su6031191.

67. Gelan A. Cash or food aid? A general equilibrium analysis for Ethiopia. Dev Policy Rev. 2006;24(5):601-24.

68. Frayne B, McCordic C. Planning for food secure cities: measuring the influence of infrastructure and income on household food security in Southern African cities. 2015; Vol. 65, pp 1-11. https://doi.org/10.1016/j. geoforum.2015.06.025. Accessed Feb 2015. 
69. Herforth A. Promotion of traditional African vegetables in Kenya and Tanzania. A case study of an intervention representing emerging imperatives in global nutrition. New York: Cornell University; 2010.

\section{Publisher's Note}

Springer Nature remains neutral with regard to jurisdictional claims in published maps and institutional affiliations.
Ready to submit your research? Choose BMC and benefit from:

- fast, convenient online submission

- thorough peer review by experienced researchers in your field

- rapid publication on acceptance

- support for research data, including large and complex data types

- gold Open Access which fosters wider collaboration and increased citations

- maximum visibility for your research: over $100 \mathrm{M}$ website views per year

At BMC, research is always in progress.

Learn more biomedcentral.com/submissions 